\title{
POLYPHENOL OXIDASE AND PEROXIDASE ENZYME ASSAYS IN SWEET POTATO CULTIVARS HARVESTED AT DIFFERENT TIMES ${ }^{1}$
}

\author{
SAMARA LOPES DE ALMEIDA ${ }^{2}$, MARIA APARECIDA DOS SANTOS MORAIS ${ }^{2}$, JOSÉ RICARDO TAVARES DE \\ ALBUQUERQUE ${ }^{3}$, AURÉLIO PAES BARROS JÚNIOR ${ }^{3}$, ADRIANO DO NASCIMENTO SIMÕES ${ }^{2}$, KELEM SILVA \\ FONSECA $^{2 *}$
}

\begin{abstract}
Enzyme assays are based on methodologies described in the literature. However, the enzyme kinetics must be adjusted to obtain more reliable results. This study aimed to adjust assays by testing different polyphenol oxidase (PPO) and peroxidase (POD) extract amounts and reaction times in sweet potato cultivars harvested at different times. Sweet potato cultivars Paraná, Mãe de Família, and ESAM1 were harvested at 120, 150 , and 180 days after planting and minimally processed. A $0.25 \mathrm{~g}$ sample was used to determine PPO and POD activities immediately after minimal processing at each harvest. Extraction was performed in $1500 \mu \mathrm{L}$ phosphate buffer $(0.2 \mathrm{M}, \mathrm{pH} 6.0)$. The PPO assay was performed by adding $10-50 \mu \mathrm{L}$ extract, $1490-1450 \mu \mathrm{L}$ phosphate buffer $(0.2 \mathrm{M}, \mathrm{pH} 6.0)$, and $1500 \mu \mathrm{L}$ catechol $(0.2 \mathrm{M})$. The POD assay was carried out by adding 10 $-50 \mu \mathrm{L}$ extract to a reaction medium containing $1790-1750 \mu \mathrm{L}$ phosphate buffer $(0.2 \mathrm{M}, \mathrm{pH} 6), 100 \mu \mathrm{l}$ guaiacol $\left(5 \mathrm{~g} \mathrm{~L}^{-1}\right)$, and $100 \mu \mathrm{L}$ hydrogen peroxide $\left(0.8 \mathrm{~g} \mathrm{~L}^{-1}\right)$. In both cases, the evaluated reaction times were 1,2 , and 3 min. In the three cultivars, PPO and POD activities increased with the volume of extract and reaction time at all harvest times. The enzyme extract volume of $10 \mu \mathrm{L}$ for $2 \mathrm{~min}$ promoted a continuous increase in PPO and POD enzyme activities in all studied cultivars and at all reaction times.
\end{abstract}

Keywords: Ipomoea batatas L. (Lam.). Standardization. Minimum processing.

\section{ENSAIOS ENZIMÁTICOS DA POLIFENOLOXIDASE E PEROXIDASE EM CULTIVARES DE BATATA DOCE COLHIDAS EM DIFERENTES ÉPOCAS}

\begin{abstract}
RESUMO - Ensaios enzimáticos são baseados em metodologias descritas na literatura. Entretanto, a cinética enzimática deve ser ajustada para resultados mais confiáveis. Objetivou-se ajustar os ensaios testando diferentes volumes de extrato de polifenoloxidase (PPO) e peroxidase (POD) e tempos de reação em cultivares de batata-doce colhidas em diferentes épocas. As cultivares Paraná, Mãe de Família e ESAM1 foram colhidas aos 120,150 e 180 dias e minimamente processadas. Amostra de $0,25 \mathrm{~g}$ foi usada para determinar as atividades de PPO e POD imediatamente após o processamento mínimo em cada colheita. A extração foi realizada em $1500 \mu \mathrm{L}$ de tampão fosfato $(0,2 \mathrm{M}, \mathrm{pH} 6,0)$. O ensaio para PPO foi realizado pela adição de 10 a $50 \mu \mathrm{L}$ de extrato, 1490 a $1450 \mu \mathrm{L}$ de tampão fosfato $(0,2 \mathrm{M}, \mathrm{pH} 6,0)$ e $1500 \mu \mathrm{L}$ de catecol $(0,2 \mathrm{M})$. O ensaio para a POD foi realizado adicionando $10-50 \mu \mathrm{L}$ de extrato a um meio de reação contendo 1790 a $1750 \mu \mathrm{L}$ de tampão fosfato $(0,2 \mathrm{M}, \mathrm{pH} 6), 100 \mu \mathrm{l}$ de guaiacol $\left(5 \mathrm{~g} \mathrm{~L}^{-1}\right)$ e $100 \mu \mathrm{L}$ de peróxido de hidrogênio $\left(0,8 \mathrm{~g} \mathrm{~L}^{-1}\right)$. Em ambos os casos, os tempos de reação avaliados foram 1, 2 e 3 min. Nas três cultivares, as atividades da PPO e POD aumentaram com o volume de extrato e tempo de reação em todas as épocas de colheita. Alíquota de $10 \mu \mathrm{L}$ de extrato por 2 minutos promoveu um incremento contínuo na atividade da PPO e POD em todas as cultivares e tempos de reação estudados.
\end{abstract}

Palavras-chave: Ipomoea batatas L. (Lam.). Padronização. Processamento mínimo.

\footnotetext{
"Corresponding author

${ }^{1}$ Received for publication in 08/30/2018; accepted in 01/16/2019.

Paper approved from III SINPROVS 2018.

Paper extracted from the masters thesis of the first author.

${ }^{2}$ Department of Production Vegetable, Universidade Federal Rural de Pernambuco, Serra Talhada, PE, Brazil; samara_lopes_almeida@hotmail.com - ORCID: 0000-0001-7820-6488, aparecida8sm@gmail.com - ORCID: 0000-0003-3529-5198, adriano.simoes@ufrpe.br - ORCID: 0000-0001-8438-2621, kelemsilva@yahoo.com.br - ORCID: 0000-0002-7136-8748.

${ }^{3}$ Department of Plant Science, Universidade Federal Rural do Semi-Árido, Mossoró, RN, Brazil; ricardoalbuquerqueagro@gmail.com ORCID: 0000-0003-4113-1501, aurelio.barros@ufersa.edu.br - ORCID: 0000-0002-6983-8245.
} 


\section{INTRODUCTION}

During the post-harvest and minimal processing stage, plants undergo numerous stresses (TOIVONEN; BRUMMELL, 2008) due to cutting, which causes cell rupture and allows the contact of enzymes with their substrate. This ultimately leads to surface darkening in the plant material (SALTVEIT et al., 1997), reducing its quality. The main enzymes related to darkening are polyphenol oxidases (PPOs) and peroxidases (PODs). PPOs (EC 1.14.18.1 monophenol monooxygenase and EC 1.10.3.2 odiphenol: oxygen oxidoreductase) are proteins that catalyse oxidation reactions of phenolic compounds, producing dark pigments from cutting or on the surface of fruits and vegetables (MISHRA; GAUTAM; SHARMA, 2013). PODs (EC 1.11.1.7) are enzymes that catalyse peroxidation, oxidationcatalytic, and hydroxylation reactions (MINIBAYEVA; BECKETT; KRANNER, 2015). They are involved in ripening and senescence, plant defence, and darkening reactions (MINIBAYEVA; BECKETT; KRANNER, 2015).

In the case of sweet cassava, darkening usually occurs slowly (FREIRE et al., 2015) compared with yam (COELHO JUNIOR et al., 2019) and sweet potato (ALMEIDA, 2018). It is known that susceptibility to darkness as well as PPO and POD enzyme activities may vary according to variety, and pre- and post-harvest management (FONSECA et al., 2018).

There is a great variability in sweet potato cultivars, which are distinguished by the colours of their skin and flesh and their shape (EMBRAPA, 2008). Cultivars with a white flesh, such as ESAM1 and Mãe de Família, exhibit higher activities of PPOs and PODs than those with a coloured flesh; e.g., cv. Paraná (orange) (ALMEIDA, 2018).

Albuquerque et al. (2017) adjusted PPO activity assays in different whole sweet potato varieties. This study concluded that a $10-\mu \mathrm{L}$ aliquot of enzyme extract in the reaction medium resulted in a linear response during the trial period, resulting in high coefficients of determination $\left(\mathrm{R}^{2}\right)$. The results of Albuquerque et al. (2017) were obtained from whole roots harvested at 120 days. However, delayed harvesting slows the darkening process in some minimally processed sweet potato cultivars (ALMEIDA, 2018), which may be a reflection of different PPO and POD activities in minimally processed tissues. Moreover, darkening as a function of harvest time may also be related to the concentration of soluble phenolic compounds, since these compounds play a role in lignin biosynthesis, especially in older roots. Thus, the darkening potential may be linked to lower availability of substrates, in addition to lower availability of oxidative enzymes (TOIVONEN; BRUMMELL, 2008; MOORTHY et al., 2011).

Enzyme assays are based on methodologies described in the literature. However, adjustments in enzyme kinetics are necessary to obtain more reliable results, since the biological behaviour can vary according to genotype and environment. In this case, studies investigating substrate type and concentration (MARTINS, 2015), reaction time, and amount of extract (ALBUQUERQUE et al., 2017) are performed. Albuquerque et al. (2017) standardised the $10-\mu \mathrm{L}$ aliquot for the PPO reaction in tissues of whole sweet potatoes harvested after 120 days of growth. In the case of sweet potatoes harvested after 120 days of growth and minimally processed, darkening is delayed during preservation (ALMEIDA, 2018). Therefore, there is a need for adjustments in the PPO and POD assays.

The present study proposes to adjust enzyme assays by investigating the extract volume and reaction time for PPO and POD enzyme activities in tissues of three cultivars of minimally processed sweet potato harvested at different times.

\section{MATERIAL AND METHODS}

The sweet potato cultivars were harvested from the experimental orchard at the Federal Rural University of the Semiarid, located in Mossoró-RN, Brazil (5 $5^{\circ} 11^{\prime} \mathrm{S} 37^{\circ} 20^{\prime} \mathrm{W} ; 18 \mathrm{~m}$ altitude). The climate in the region is hot and dry (semiarid), classified as a BShw type (Köppen) with two welldefined climatic seasons: rainy (February to May) and dry (June to January) (CARMO FILHO; OLIVEIRA, 1989). The soil in the experimental area is classified as Argissolo Vermelho-Amarelo Eutrófico Abrupto (Ultisol) of frank sandy texture (SANTOS et al., 2013).

Roots of sweet potato cultivars Paraná, Mãe de Família, and ESAM1 were harvested after 120, 150 , and 180 days of growth. Once harvested, they were transported to the Laboratory of the Postgraduate Program in Plant Production at the Federal Rural University of Pernambuco/Serra Talhada Academic Unit, located in Talhada-PE, Brazil.

In selecting the roots, those that did not fit marketability standards were discarded and only those of high quality were kept. These were washed under running water and the periderm was removed. The roots were chopped into slices with an average standard thickness of $2 \mathrm{~cm}$ and diameter varying according to each cultivar. The cultivar Paraná had an average diameter of $4.5 \mathrm{~cm}$; cv. Mãe de Família, $3.5 \mathrm{~cm}$; and cv. ESAM1, $4.0 \mathrm{~cm}$. Soon afterwards, the slices were rinsed in water at $5^{\circ} \mathrm{C}$ for $10 \mathrm{~s}$, followed by sanitisation in solution containing 200 $\mathrm{mg} \mathrm{L} \mathrm{L}^{-1}$ active chlorine for $10 \mathrm{~min}$ and water at $5^{\circ} \mathrm{C}$. Lastly, the material was rinsed again in water containing $5 \mathrm{mg} \mathrm{L}^{-1}$ active chlorine at $5^{\circ} \mathrm{C}$ for 10 min. The slices were then drained in domestic drainers for $10 \mathrm{~min}$. Afterwards, they were packed in 
polypropylene packages $(150 \times 200 \times 0.0006 \mathrm{~mm}$ thickness) kept at $5 \pm 2{ }^{\circ} \mathrm{C}$. Subsequently, $0.25 \mathrm{~g}$ of plant tissue was removed to determine PPO and POD activities. The material was then macerated in $6 \mathrm{~mL}$ cold sodium phosphate buffer $(0.2 \mathrm{M}, \mathrm{pH} 6.0)$. The extract was centrifuged at $7960 \times \mathrm{g}$ for $23 \mathrm{~min}$ at $4^{\circ}$ C. The PPO assay was performed according to Simões et al. (2015), by adding different volumes of extract; namely, $10,20,30,40$, and $50 \mu \mathrm{L}$ of the supernatant to the reaction medium containing 1490 , $1480,1470,1460$, and $1450 \mu \mathrm{L}$, respectively, of phosphate buffer $(0.2 \mathrm{M}, \mathrm{pH}$ 6.0) and $1500 \mu \mathrm{L}$ catechol $(0.2 \mathrm{M})$. Readings were taken using a spectrophotometer (Libra S8, Biochrom, Cambridge, UK) at $425 \mathrm{~nm}$ at $25^{\circ} \mathrm{C}$ for 1,2 , and 3 min with $30 \mathrm{~s}$ intervals between readings. PPO activity was calculated based on the molar extinction coefficient of $3400 \mathrm{mM}^{-1} \mathrm{~cm}^{-1}$ for catechol and expressed in $\mu \mathrm{mol} \min ^{-1} \mathrm{~g} \mathrm{FM}^{-1}$. For the control, catechol was replaced with the reaction buffer.

The POD assay was performed according to Simões et al. (2015), by adding different volumes of extract; namely, 10, 20, 30, 40, and $50 \mu \mathrm{L}$ of the supernatant to the reaction medium containing 1790 , $1780,1770,1760$, and $1750 \mu \mathrm{L}$, respectively, of phosphate buffer $(0.2 \mathrm{M}, \mathrm{pH} 6.0), 100 \mu \mathrm{L}$ guaiacol (5 $\left.\mathrm{g} \mathrm{L}^{-1}\right)$, and $100 \mu \mathrm{L}$ hydrogen peroxide $\left(0.8 \mathrm{~g} \mathrm{~L}^{-1}\right)$. Readings were taken using a spectrophotometer
(Libra S8, Biochrom, Cambridge, UK) at $470 \mathrm{~nm}$ at $30^{\circ} \mathrm{C}$ every 1,2 , and $3 \mathrm{~min}$. POD activity was calculated based on the molar extinction coefficient of $26.6 \mathrm{mM}^{-1} \mathrm{~cm}^{-1}$ for guaiacol and expressed in $\mu \mathrm{mol} \mathrm{min}^{-1} \mathrm{~g} \mathrm{FM}^{-1}$. For the control, guaiacol was replaced with the reaction buffer.

Regression analysis was carried out using the means of the replicates of five extract volumes $(10$, $20,30,40$, and $50 \mu \mathrm{L})$ and three reading times $(1,2$, and $3 \mathrm{~min})$. The analysis was performed for three sweet potato cultivars (Paraná, Mãe de Família, and ESAM1) and three harvest times (120, 150, and 180 days).

\section{RESULTS AND DISCUSSION}

The slopes of the curves, also known as angular coefficients of the regression equations, for PPO and POD activities, increased with reaction time in the three cultivars (Paraná, Mãe de Família and ESAM1) and at the three harvest times (120, 150, and 180 days; Figures 1, 2 and 3). Furthermore, these slopes at 2 and $3 \mathrm{~min}$ showed more similar absolute values than the slope at 1 min (Figures 1, 2 and 3). Increasing volumes of extract increased the PPO and POD enzyme activities (Figures 1, 2 and 3).

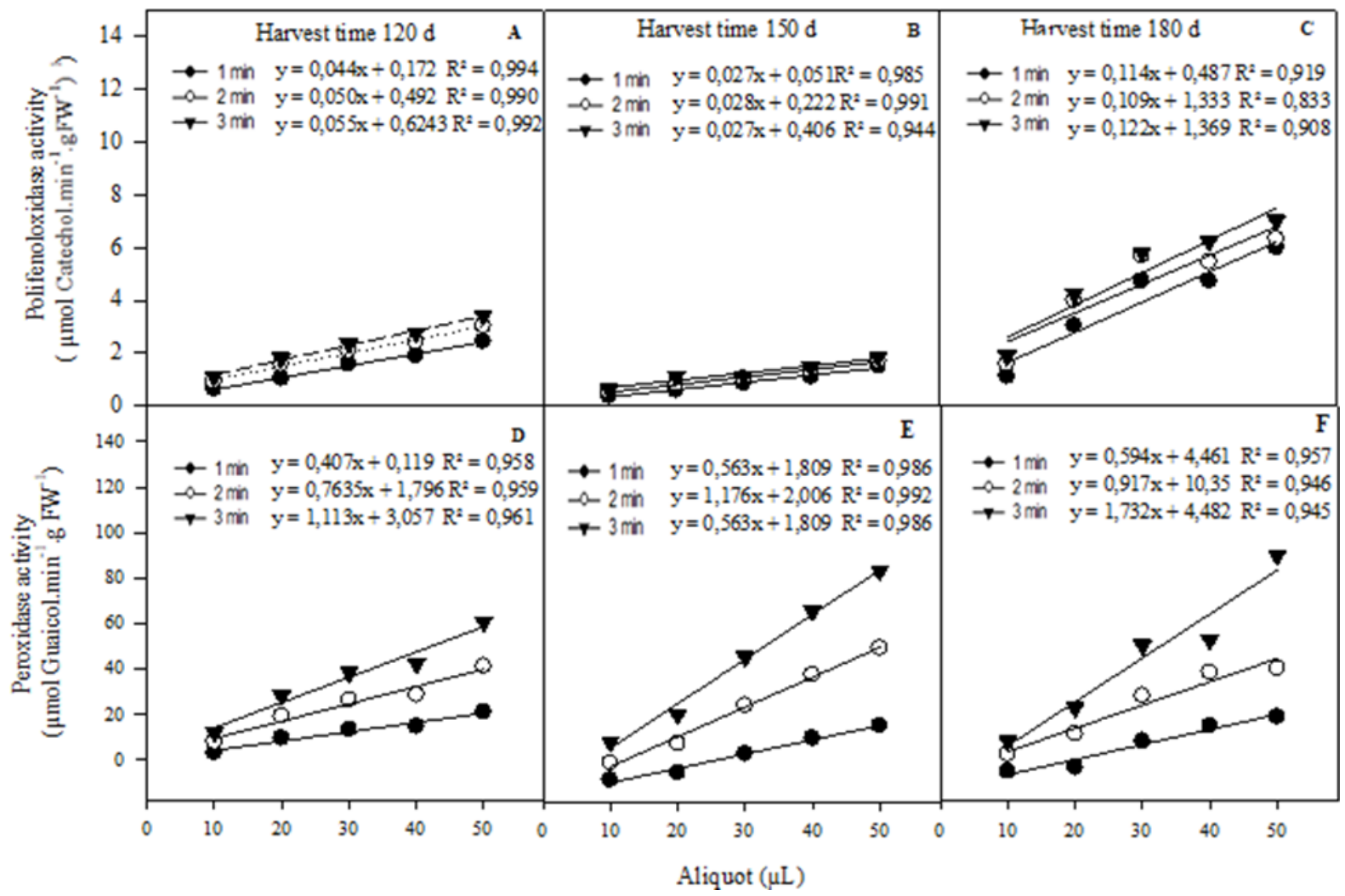

Figure 1. The activity of polyphenol oxidase and peroxidase enzymes in sweet potato roots of the Paraná cultivar, minimally processed immediately after the minimum processing, and harvested at 120 (A, D), 150 (B, E) and 180 (C, F) days at the time of readings 1,2 and 3 minutes, respectively. 


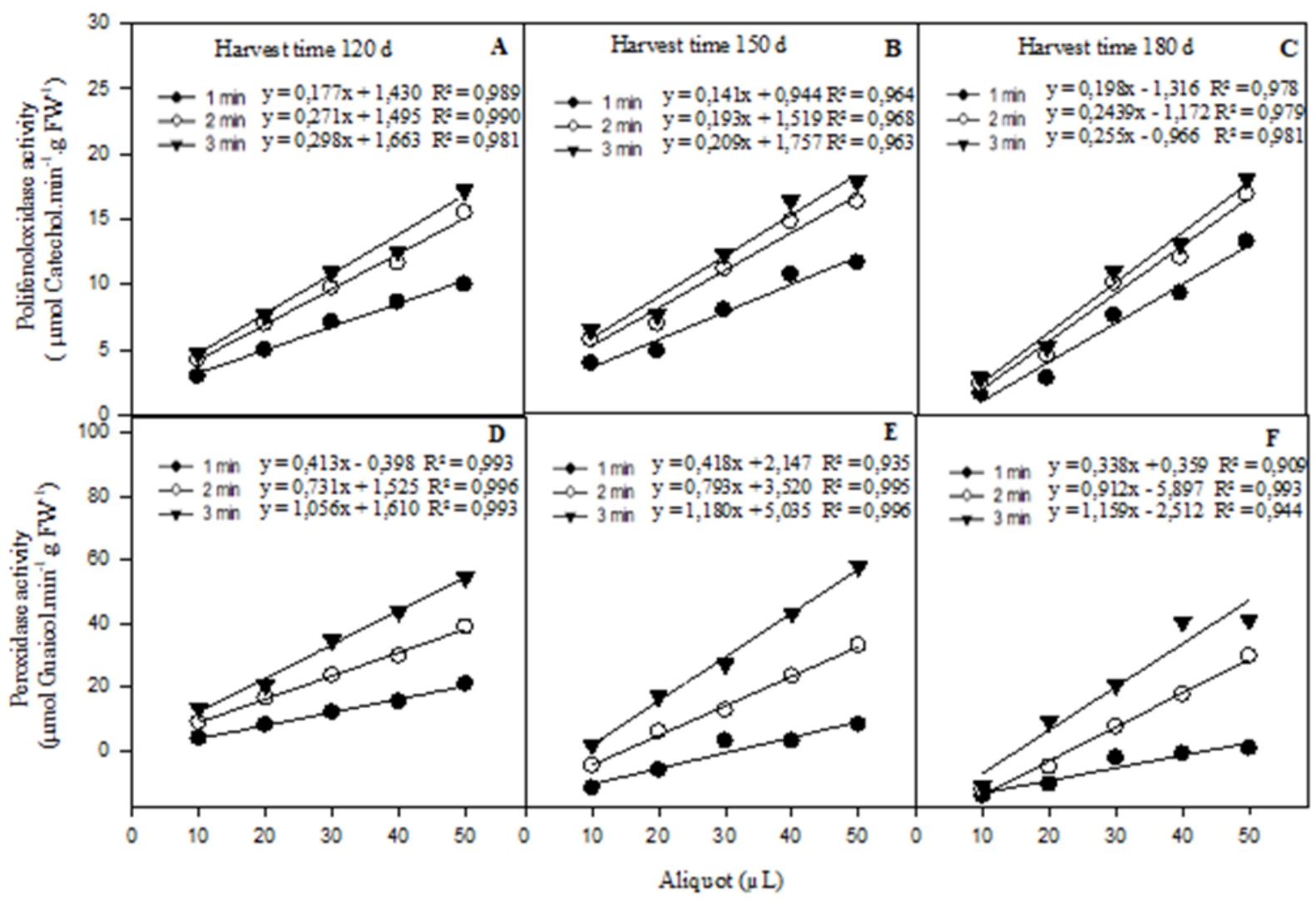

Figure 2. The activity of polyphenol oxidase and peroxidase enzymes in sweet potato roots of the Mãe de Família cultivar, minimally processed immediately after the minimum processing, and harvested at 120 (A, D), 150 (B, E) and 180 (C, F) days at the time of readings 1,2 and 3 minutes, respectively.

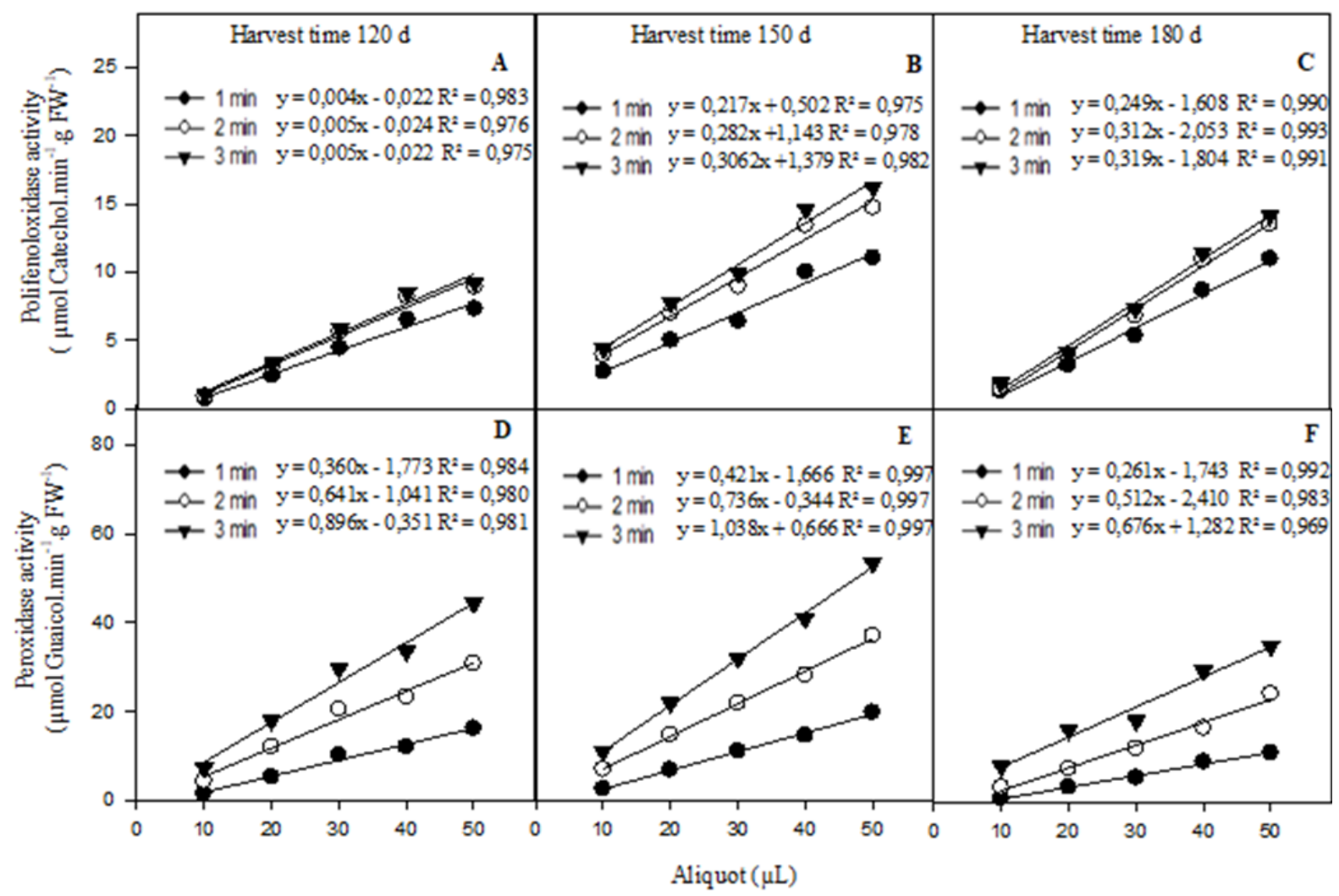

Figure 3. The activity of polyphenol oxidase and peroxidase enzymes in sweet potato roots of the ESAM 1 cultivar, minimally processed immediately after the minimum processing, and harvested at 120 (A, D), 150 (B, E) and 180 (C, F) days at the time of readings 1,2 and 3 minutes, respectively. 
In all cases, the response curve at the studied times and extract volumes showed high linearity $(>90 \%)$. This enabled the use of the tested volumes and times for the study of preservation of the sweet potato cultivars Paraná, Mãe de Família, and ESAM1. Simões et al. (2016) used $50 \mu \mathrm{L}$ of plant extract to evaluate PPO enzyme activity in yam (Discorea sp.). Ramos et al. (2013) used an enzyme extract volume of $500 \mu \mathrm{L}$ in cassava (Manihot esculenta Crantz). A $10 \mu \mathrm{L}$ aliquot of enzyme extract for sweet potato cvs. ESAM2, ESAM3, and Sr. Antônio exhibited a slight loss of linearity above that volume, which may indicate some external influence; e.g., absence of substrate or reaction inhibition (ALBUQUERQUE et al., 2017). It is noteworthy that Albuquerque et al. (2017) recommended a volume of $10 \mu \mathrm{L}$. In this case, the authors used $1 \mathrm{~g}$ of fresh matter. In the current experiment, $0.25 \mathrm{~g}$ was used for the same extract volume $(10 \mu \mathrm{L})$. This shows that minimal processing stimulates the activity of these enzymes, making the fresh mass of the sample smaller for the same response magnitude. It should also be stressed that a smaller working volume allows for decreased expenditure on reagents and smaller, more compact equipment such as microcentrifuges. This can maximise the development of laboratory procedures. A volume of $10 \mu \mathrm{L}$ is thus suggested as a standard for the determination of PPO and POD activities, although no linearity loss occurred, as observed by the $\mathrm{R}^{2}$ greater than 0.9 in all cases.

Determining $K_{m}$ was not a focus of the present study, since the substrates were the same and the concentration used was well defined in previous studies: catechol for PPO and guaiacol and hydrogen peroxide for peroxidase (AQUINO-BOLAÑOS; MERCADO-SILVA, 2004; ZAHANG; SHAO, 2015). The objective of the present study was to determine the volumes and reaction times that resulted in linear enzyme activity, with no undesirable external interference that caused loss of linearity; e.g., lack of substrate or reaction inhibition, considering that other experimental conditions such as wavelength, reaction time, and substrate concentration were standardised.

The present results also demonstrated that the angular coefficient represented by the slopes of the curves were higher in the white-flesh cultivars (ESAM1, followed by Mãe de Família) than in the orange-flesh cultivar (Paraná) (Figures 1, 2 and 3). This may be a biochemical indicator that white cultivars are more susceptible to darkening than coloured cultivars, which warrants further investigation. These differences in enzyme activities in the tissues of minimally processed sweet potato according to flesh colour also show that these potatoes can activate, by still non-elucidated reasons, signalling and metabolic pathways, inducing the synthesis of phenolic compounds (JACOBOVELÁZQUEZ; CISNEROS-ZEVALLOS, 2012).
This prompts changes in enzyme activities (PPO and POD), which may use phenolic compounds as substrates and lead to darkening in slices of beigeflesh sweet potato, as is the case in the cultivars ESAM1 and Mãe de Família (ALMEIDA, 2018). However, in the Paraná cultivar, whose flesh is orange, darkening is not as noticeable compared with beige-flesh potatoes (ALMEIDA, 2018). In this regard, PPO and POD enzyme activities involved in this oxidative damage should be examined in greater detail.

Finally, at the reaction time of $3 \mathrm{~min}$, there was no proportional increase in the slope of the curve for PPO activity compared with 1 and $2 \mathrm{~min}$. This may indicate some interference in the reaction that may result in loss of linearity (Figures 1, 2 and 3). However, this was not true for POD activity, for which the increases in slopes were proportional to the increases in reaction time from 1 to $3 \mathrm{~min}$ (Figures 1, 2 and 3). Under such conditions, these findings suggest a standard time of up to $2 \mathrm{~min}$ for determining PPO and POD activities.

\section{CONCLUSIONS}

The studied experimental conditions, $0.25 \mathrm{~g}$ fresh mass and $10 \mu \mathrm{L}$ volumes for 2 min, resulted in linear increases in absorbance. Therefore, they are adequate parameters for standardising laboratory protocols for determining PPO and POD enzyme activities in the roots of minimally processed sweet potato.

\section{ACKNOWLEDGMENTS}

CAPES (Process: 88881-159183/2017-01), CNPq and FACEPE (Processes: BCT-0191-5.01/17 and APQ-0795-5.01/16).

\section{REFERENCES}

ALBUQUERQUE, J. R. T. et al. Adequacy of the extract aliquot for determining the activity of polyphenoloxidase in sweet potato varieties. Amazonian Journal of Plant Research,v. 1, n. 1, p. 20-23, 2017.

ALMEIDA, S. L. Cultivares de batata doce colhidas em diferentes épocas para processamento mínimo. 2018. 76 f. Dissertação (Mestrado em Produção Vegetal: Área de Concentração em Produção Vegetal no Semiárido) - Universidade Federal Rural de Pernambuco, Serra Talhada, 2018.

AQUINO-BOLAÑOS, E. N.; MERCADO-SILVA, E. Effects of polyphenol oxidase and peroxidase 
activity, phenolics and lignin content on the browning of cut jicama. Postharvest Biology and Technology, v. 33, n. 3, p. 275-283, 2004.

CARMO FILHO F.; OLIVEIRA, O. F. Mossoró: um município do semiárido nordestino "Características climáticas e aspectos florísticos". Mossoró, RN: ESAM, 1989. 62 p. (Coleção Mossoroense, 672).

COELHO JUNIOR, L. F. et al. Darkening, damage and oxidative protection are stimulated in tissues closer to the yam cut, attenuated or not by the environment. Journal of the Science of Food and Agriculture, v. 99, n. 1, p. 334-342, 2019.

EMPRESA BRASILEIRA DE PESQUISA AGROPECUÁRIA - EMBRAPA. Centro Nacional de Pesquisa de Hortaliças. Cultivo da batata doce (Ipomoea batatas). Sistemas de Produção, 6. 2008. Disponível em: <http:// sistemasdeproducao.cnptia.embrapa.br/ FontesHTLM/Batatadoce/Batata doce_Ipomoea_batatas/referencias.html $>$. Acesso em: $\overline{07}$ ago. $20 \overline{1} 8$.

FREIRE SOARES, C. et al. Activity of oxidative enzymes involved in the browning of minimally processed sweet cassava ('Manihot esculenta' Crantz). Australian Journal of Crop Science, v. 9, n. 4, p. 296-302, 2015.

FONSECA, K. S. et al. Baby Cassava: An Alternative Marketing Strategy for Freshly Cut Cassava. In: WAISUNDARA, V. (Ed.). Cassava. Reino Unido, Londres: IntechOpen. 2018, v. 1, cap. 11, p. 185-198.

JACOBO-VELÁZQUEZ， D. A.; CISNEROSZEVALLOS, L. An alternative use of horticultural crops: stressed plants as biofactories of bioactive phenolic compounds. Agriculture, v. 2, n. 1, p. 259$271,2012$.

MARTINS, A. R. Representação do efeito de inibição enzimática reversível para o modelo cinético de Michaelis-Menten no estado transiente. Brazilian Journal of Food Technology, v. 18, n. 2, p. 112$120,2015$.

MINIBAYEVA, F.; BECKETT, R. P.; KRANNER, I. Roles of apoplastic peroxidases in plant response to wounding. Phytochemistry, v. 112, n. 1, p. $122-$ $129,2015$.

MISHRA, B. B.; GAUTAM, S.; SHARMA, A. Free phenolics and polyphenol oxidase (PPO): The factors affecting post-cut browning in eggplant (Solanum melongena). Food Chemistry, v. 139, n. 1, p. 105-
144,2013

MOORTHY, S. N. et al. Swett Potato Starch: Physico Chemical, Funtional, Therman and Rheological Characteristics. Fruit, Vegetable and Cereal Science and Biotechnology, v. 6, n. 1, p. 124-133, 2011.

RAMOS, P. A. S. et al. Effect of peroxidase inhibitors on the conservation of fresh cassava roots. Brazilian Journal of Food Technology, v. 16, n. 2, p. 116-124, 2013.

SALTVEIT, M. E. Physical and physiological changes in minimally processed fruits and vegetables. In: TOMÁS-BARBERÁN, F. A.; ROBINS, R. J. (Eds.). Phytochemistry of Fruit and Vegetables. London: Oxford University Press, 1997. p. 205-220.

SIMÕES, A. N. et al. The effects of storage temperature on the quality and phenolic metabolism of whole and minimally processed kale leaves. Acta Scientiarum. Agronomy, v. 37, n. 1, p. 101-107, 2015

SIMÕES, A. N. et al. Quality of minimally processed yam (Dioscorea sp.) stored at two different temperatures. Revista Caatinga, v. 29, n. 1, p. 25-36, 2016.

SANTOS, H. G. et al. Sistema Brasileiro de Classificação de Solos. 3. ed. Brasília, DF: Embrapa Solos, 2013. $353 \mathrm{p}$.

TOIVONEN, P. M. A.; BRUMMELL, D. A. Biochemical bases of appearance and texture changes in fresh-cut fruit and vegetables. Postharvest Biology and Technology, v. 48, n. 1, p. $1-14,2008$.

ZAHANG, X.; SHAO, X. Characterisation of polyphenol oxidase and peroxidase and the role in browning of loquat fruit. Czech Journal of Food Sciences, v. 33, n. 2, p. 109-117, 2015. 